\title{
Pelaksanaan Evaluasi Hasil Belajar Mahasiswa
}

\author{
Nelfia Adi \\ Dosen Universitas Negeri Padang
}

\begin{abstract}
Abstrak: Penelitian ini bertujuan untuk mengetahui pelaksanaan evaluasi hasil belajar yang dilakukan oleh dosen Universitas Negeri Padang (UNP) yang meliputi: Pembuatan kisi-kisi tes, pembuatan soal, pelaksanaan pengukuran, pelaksanaan penskoran, pelaksanaan dan pengadministrasian hasil penilaian, Hasil penelitian ini menunjukkan bahwa $42 \%$ dosen selalu membuat kisi-kisi tes. Dalam pembuatan soal $37 \%$ dosen selalu mempedomani criteria dalam pembuatan soal. Selanjutnya, dalam melakukan kegiatan pengukuran sebanyak $75 \%$ selalu melaksanakan pengukuran, sementara itu $47 \%$ dosen juga selalu melakukan penilaian dan melakukan pengadministrasian hasil belajar mahasiswa. Berdasarkan hasil temuan penelitian ini dapat diartikan bahwa; pelaksanaan evaluasi hasil belajar oleh dosen UNP dapat dikategorikan baik. Karena belum semua dosen melaksanakan evaluasi hasil belajar dengan sempurna, maka hasil belajar mahasiswa perlu ditingkatkan lagi pelaksanaannya sesuai dengan ketentuan yang ada.
\end{abstract}

Kata kunci: tes, pengukuran evaluasi hasil belajar, keputusan, dan administrasi

\begin{abstract}
The purpose of this study is to determine the process of the evaluation conducted by the lecturers of UNP, including lattice-making testing, manufacturing problems, the implementation of measurement, assessment and administration of the assessment results. Results revealed that as many as $42 \%$ of lecturers stated always pay attention to making the test grating. There were about $37 \%$ of lecturers stated always an often pay attention to the criteria in writing about. In the normal measurement of $75 \%$ of lecturers used to pay attention to implementation. In the normal scoring $47 \%$ of lecturers stated always and often pay attention to implementation. In conducting the assessment and administration of student learning outcomes, $53 \%$ of lecturers claimed always and often pay attention to implementation. Based on these reseaech results may imply that the implementation of the evaluation of learing outcomes by the lectures of UNP normally located in the category well enough, its implementation still needs to be improved again by the lecturers.
\end{abstract}

Key words: test, measurement, learning evaluation, assessment and administration

\section{Pendahuluan}

Universitas Negeri Padang (UNP) sebagai salah satu lembaga pendidikan tinggi negeri di kota Padang secara umum melaksanakan program pendidikan dengan berpedoman pada Pancasila dan UUD 1945. Selanjutnya pengembangan dari dasar program pendidikan yang dilaksanakan di UNP dirumuskan secara jelas dalam visi dan misi yang berguna untuk membentuk arahan bagi setiap sivitas akademika dalam menjalankan segala hak dan kewajibannya.

Agar visi dan misi UNP dapat terlaksana dengan baik diperlukan dukungan dari para sivitas akademika yang antara lain didalamnya, yaitu; pelaksana akademik, pelaksana administrasi, unit penunjang, mahasiswa, dosen dan sebagainya.

Dosen sebagai pelaksana akademik merupakan tenaga pendidik yang memiliki tugas utama mengajar. Dalam Buku Pedoman Akademik Universitas Negeri Padang (UNP) 2001 pasal 5 dijelaskan bahwa tugas utama dosen adalah memberikan kuliah/praktikum, membimbing, melatih mahasiswa, serta melakukan penelitian dan pengabdian kepada masyarakat. Dalam memberikan kuliah/praktikum setiap dosen harus mempersiapkan bahan untuk kuliah/praktikum, tepat waktu dalam jadwal kegiatan akademik dan melakukan evaluasi terhadap kemajuan belajar 
mahasiswa yang bertujuan untuk remedial ataupun untuk menentukan keberhasilan belajar mahasiswa.

Salah satu alat utama untuk mengetahui kemajuan belajar mahasiswa adalah dengan melakukan evaluasi. Evaluasi bertujuan untuk mengetahui keberhasilan penyelenggaraan akademik serta memperoleh umpan balik bagi mahasiswa dan dosen. Guna mencapai tujuan evaluasi tersebut, maka dilaksanakan ujian akhir semester dan bentuk ujian lainnya. Tujuan tersebut dapat dilakukan secara tertulis, lisan, tugas rumah, ujian keterampilan dan bentuk ujian lainnya.

Berdasarkan ketentuan yang telah ada untuk pelaksanaan evaluasi hasil belajar mahasiswa di UNP seperti yang telah dikemukakan diatas, maka lebih lanjut para dosen perlu membuat perencanaan yang jelas dari kegiatan evaluasi yang akan dilakukannya, malaksanakan pengukuran dan dilanjutkan dengan penilaian serta pengadministrasian hasil penilaian. Kegiatan-kegiatan ini perlu dilakukan karena pada dasarnya evaluasi merupakan suatu proses untuk menentukan nilai segala sesuatu dalam dunia pendidikan atau segala sesuatu yang ada hubungannya dengan dunia pendidikan (Nurkancana, 1983: 1). Berdasarkan pendapat Nurkancana tersebut terlihat bahwa dalam pelaksanaan kegiatan evaluasi yang dilakukan hendaklah terencana dengan jelas sehingga proses menentukan nilai dari hasil belajar siswa tersebut dapat dilakukan dengan sebaik-baiknya sesuai ketentuan yang berlaku.

Pelaksanaan evaluasi hasil belajar di UNP yang dilakukan oleh dosen, baik evaluasi hasil belajar tengah semester, maupun akhir semester belum berjalan secara optimal. Hal ini terlihat adanya ketidakpuasan dari pihak mahasiswa terhadap nilai yang diberikan oleh dosen. Ketidakpuasan mahasiswa tersebut dapat dilihat adanya komplain dari mahasiswa terhadap nilai yang diperoleh dari hasil evaluasi belajar.

Di samping itu, terdapat adanya keluhan dari mahasiswa ketika mengikuti ujian karena soalsoal yang mereka terima tentang materi yang diuji belum disampaikan dalam perkuliahan, sehingga mereka bingung untuk memberikan jawabannya.

Beberapa keluhan dari mahasiswa yang dikemukakan di atas dapat disimpulkan bahwa evaluasi yang dilakukan oleh dosen belum berjalan dengan baik. Sehingga perlu dipertanyakan apakah para dosen telah melakukan kegiatan evaluasi sebagaimana mestinya sesuai dengan ketentuan yang berlaku?

Sementara itu dipihak dosen sendiri, menurut pengamatan yang peneliti lakukan mengenai kegiatan evaluasi oleh dosen memang ada yang belum dilakukan sebagaimana mestinya. Hal ini terlihat dari ada sebagian dosen yang membuat soal untuk ujian waktu sudah berada di kelas atau beberapa menit sebelum ujian dilakukan, sehingga terkesan belum adanya rencana yang jelas untuk ujian yang dilakukan. Belum adanya perencanaan yang baik, maka ujian yang dilakukan diduga belum dapat mengukur secara keseluruhan penguasaan mahasiswa terhadap materi yang dipelajari dalam kegiatan perkuliahan. Di samping itu, terlihat bahwa bentuk soal yang diberikan oleh dosen adalah dalam soal essay. Secara umum soal dalam bentuk essay ini bukanlah bentuk soal yang terbaik, tetapi juga ada kelemahan yang dapat diatasi dengan memberikan bentuk soal yang lain.

Dari gambaran yang telah dipaparkan di atas penelitian ini secara umum secara umum penelitian ini bertujuan untuk mengetahui pelaksanaan evaluasi hasil belajar yang dilakukan dosen UNP yang meliputi: pembuatan kisi-kisi tes, pembuatan soal, pelaksanaan pengukuran, pelaksanaan penilaian, dan pengadministrasian hasil penilaian.

\section{Kajian Teori}

Evaluasi atau penilaian merupakan kegiatan yang selalu dilakukan dalam kehidupan sehari-hari. Apapun yang akan dilakukan seseorang biasanya terlebih dahulu, selalu dinilai kegiatan tersebut supaya dapat memberikan hasil yang diinginkan. Stuffle Beam (1972: 25) memberikan batasan sebagai berikut: "Evaluation is the process of delinating, obtaining, and providing useful information for judging decision alternative".

Sementara itu Bloom dalam Silverius (1991: 4) mengemukakan bahwa evaluasi sebagaimana kita lihat adalah pengumpulan kenyataan secara sistimatis untuk menetapkan apakah dalam kenyataannya terjadi perubahan dalam diri siswa dan menetapkan sejauhmana tingkat perubahan dalam diri pribadi siswa. 
Sudjana (1989: 3), menyatakan bahwa: Evaluasi atau penilaian merupakan suatu proses memberikan atau menentukan nilai kepada objek tertentu berdasarkan suatu kriteria tertentu. Proses pemberian nilai tersebut berlangsung dalam bentuk interpretasi yang diakhiri dengan judgment. Pendapat sama yang dikemukakan oleh Poulson dalam Soekartawi (1995:10) menyatakan "evaluasi adalah proses menguji suatu obyek keperluan pembuatan keputusan". Arikunto (1999: 3) juga mengemukakan pendapat tentang evaluasi yaitu: mengukur dan menilai. Mengukur diartikan membandingkan sesuatu dengan sesuatu ukuran. Pengukuran bersifat kuantitatif. Menilai adalah mengambil suatu keputusan terhadap sesuatu dengan ukuran baik atau buruk. Penilaian bersifat kualitatif.

Evaluasi yang dilakukan oleh dosen tentulah memiliki tujuan dan fungsi. Silverius (1991: 9) mengemukakan tujuan dan fungsi evaluasi sebagai berikut: Tujuan utama evaluasi dalam PBM adalah mendapatkan informasi yang akurat mengenai ketercapaian tujuan instruksional oleh siswa, sehingga dapat diupayakan tindak lanjutnya. Tindak lanjutnya termaksud merupakan fungsi evaluasi dan dapat berupa: 1) Penempatan pada tempat yang tepat; 2) Pemberian umpan balik; 3) Diagnosis kesulitan belajar siswa; dan 4) Penentuan kelulusan.

Dalam melaksanakan penilaian, hendaklah memperhatikan prinsip-prinsip penilaian sehingga penilaian yang dilakukan dapat memenuhi ketentuan yang berlaku. Sudjana (1989: 8-9) berpendapat prinsip penilaian antara lain: a) Dalam menilai hasil belajar hendaknya dirancang sedemikian rupa sehingga jelas abilitas yang dinilai, materi penilaian, alat penilaian dan interpretasi hasil penilaian; b) Penilaian hasil belajar hendaklah bagian integral dari PBM; c) Agar diperoleh hasil belajar yang objektif, penilaian hendaklah menggunakan berbagai alat dan sifatnya komprehensif; dan d) Penilaian hasil belajar hendaknya diikuti dengan tindak lanjut.

Berdasarkan penjelasan di atas, dapat diartikan dalam melaksanakan evaluasi hasil belajar hendaklah dilakukan mengikuti prosedur tertentu dan jelas fungsi serta tujuannya dan memperhatikan prinsip-prinsip penilaian yang berlaku.
Adapun prosedur yang akan dilakukan dalam kegiatan evaluasi hasil belajar tersebut menurut Yulien Stanley seperti dikutip Nurkancana (1983: 6-7) terdiri dari: Menetapkan tujuan program, memilih alat yang layak, pelaksanaan pengukuran, memberikan skor, menganalisis dan menginterpretasi skor, membuat catatan yang baik, dan menggunakan hasil-hasil.

Lebih lanjut Buchari (1972: 24) berpendapat "Langkah-langkah pokok evaluasi terdiri dari perencanaan, pengumpulan data, verifikasi data, analisa data dan penafsiran data". Selanjutnya Sudjana (1989: 9-10) berpendapat bahwa prosedur evaluasi tersebut meliputi, antara lain: a) Merumuskan atau mempertegas tujuan pengajaran sehingga dapat memberikan arah terhadap penyusunan alat penilaian; b) Mengkaji kembali materi pengajaran berdasarkan kurikulum, karena penguasaan materi pengajaran merupakan isi dari sasaran penilaian hasil belajar; c) Menyusun alat penilaian baik tes maupun nontes. Dalam penyusunan alat penilaian hendaklah memperhatikan kaidah penulisan soal; d) Menggunakan hasil penilaian sesuai tujuan penilaian.

Dari beberapa pendapat para ahli tentang prosedur evaluasi dapat disimpulkan bahwa langkah-langkah dalam melakukan evaluasi dimulai dengan perencanaan evaluasi, pelaksanaan pengukuran, menganalisis data hasil pengukuran, melakukan penilaian dan mengadministrasikan hasil penilaian. Khusus untuk kepentingan penelitian ini maka penelitian yang akan dilakukan tentang perencanaan, meliputi kegiatan pembuatan kisi-kisi tes dan penulisan soal, dan dilanjutkan dengan kegiatan pengukuran, penskoran, penilaian dan administrasi hasil penilaian.

\section{Metode Penelitian}

Jenis penelitian ini adalah penelitian deskriptif. Rahmad yang dikutip oleh Hadjar (1996:16), mengemukakan bahwa penelitian deskriptif adalah penelitian yang berusaha membuat deskripsi fenomena yang terjadi dengan cara menuliskan dan mengklarifikasikan fakta dan karakteristik fenomena tersebut secara faktual dan tepat.

Populasi penelitian ini adalah seluruh dosen UNP yang melaksanakan kegiatan pengajaran, 
secara keseluruhan jumlah staf pengajar tersebut sebanyak 881 orang.

Penentuan sampel dilakukan dengan teknik Stratified Random Sampling, yakni sebanyak $10 \%$ dari masing-masing tingkat pendidikan dosen. Jumlah dosen yang terpilih menjadi sampel penelitian sebanyak 90 orang.

Penelitian ini terdiri dari satu variabel yaitu Pelaksanaan Evaluasi Hasil Belajar oleh Dosen UNP. Variabel tersebut dirinci menjadi sub-sub variabel yaitu: pembuatan kisi-kisi tes, pembuatan soal, pelaksanaan pengukuran, pelaksanaan penilaian, pengadministrasian hasil belajar mahasiswa.

Jenis data yang diperlukan dalam penelitian ini adalah data primer, yaitu data tentang Pelaksanaan Evaluasi Hasil Belajar oleh Dosen UNP. Jenis data yang diperlukan tersebut meliputi data tentang: pembuatan kisi-kisi tes, pembuatan soal, pelaksanaan pengukuran, pelaksanaan penilaian, pengadministrasian hasil penilaian.

Sumber data dalam penelitian ini adalah seluruh dosen-dosen UNP. Teknik dan alat yang digunakan untuk mengumpulkan data adalah angket dengan model skala Likert dengan empat alternatif jawaban.

Data yang terkumpul diolah dengan teknik persentasi dengan rumus persentase sebagai berikut:

$$
P=\frac{f \times 100 \%}{N}
$$

\section{Hasil}

Dari 90 angket yang disebarkan kepada responden yang dikembalikan sebanyak 86 (95\%) atau sebanyak empat orang tidak mengembalikan angket penelitian (5\%). Dari 86 angket dikembalikan tersebut tiga (3) angket tidak diolah, karena tidak diisi secara lengkap oleh responden. Dengan demikian angket yang dapat diolah dalam penelitian ini sebanyak 83 eksemplar (92\%). Arikunto mengatakan pengembalian angket penelitian di atas $90 \%$ merupakan pengembalian kategori tinggi (1999: 24), sehingga data yang terkumpul dapat diolah dan dapat menjawab permasalahan penelitian.

Angket yang digunakan dalam penelitian ini berbentuk skala likert dengan empat (4) alternatif jawaban, yaitu selalu(SL) dengan rentangan $76 \%-100 \%$, sering (SR) dengan rentangan 51\%$75 \%$, kadang-kadang(KD) dengan rentangan $26 \%-50 \%$ dan tidak pernah dengan rentangan $0 \%-25 \%$.

Hasil penelitian tentang pelaksanaan evaluasi hasil belajar mahasiswa oleh dosen UNP adalah sebagai berikut.

Pada Tabel 1 terlihat bahwa rata-rata prosedur penilaian hasil belajar responden menyatakan selalu dan sering memperhatikan pelaksanaan prosedur penilaian hasil belajar mahasiswa dan sebagian lagi ada yang menyatakan kadang-kadang dan tidak pernah. Dalam prosedur penilaian hasil belajar yang dilakukan, responden menyatakan: 1) 15 responden (18\%)

Tabel 1. Rekapitulasi Rata-rata Pelaksanaan Penilaian Hasil Belajar Mahasiswa oleh Dosen UNP

\begin{tabular}{|c|c|c|c|c|c|c|c|c|c|c|c|}
\hline \multirow{2}{*}{ No } & \multirow{2}{*}{ Pernyataan } & \multicolumn{2}{|c|}{ SL } & \multicolumn{2}{|c|}{ SR } & \multicolumn{2}{|c|}{ KD } & \multicolumn{2}{|c|}{ TP } & \multicolumn{2}{|c|}{ Total } \\
\hline & & $f$ & $\%$ & $F$ & $\%$ & $f$ & $\%$ & $f$ & $\%$ & f & $\%$ \\
\hline 1 & Pembuatan kisi-kisi & 15 & 18 & 20 & 24 & 21 & 25 & 28 & 34 & 83 & 100 \\
\hline 2 & Penulisan soal & 11 & 13 & 20 & 24 & 19 & 23 & 32 & 29 & 83 & 10 \\
\hline 3 & Pelaksanaan pengukuran & 49 & 59 & 13 & 16 & 11 & 13 & 10 & 12 & 83 & 100 \\
\hline 4 & Pelaksanaan penskoran & 29 & 35 & 10 & 12 & 14 & 16 & 31 & 37 & 83 & 10 \\
\hline 5 & $\begin{array}{l}\text { Pelaksanaan penilaian dan administrasi } \\
\text { hasil tes belajar }\end{array}$ & 23 & 27 & 30 & 36 & 21 & 26 & 9 & 11 & 83 & 100 \\
\hline & Rata-rata & 25 & 31 & 19 & 23 & 17 & 21 & 22 & 25 & 83 & 100 \\
\hline
\end{tabular}


selalu dan 20 responden (24\%) menyatakan sering membuat kisi-kisi tes, sebagian lagi jarang dan tidak pernah; 2) sebanyak 11 responden (13\%) menyatakan selalu dan 20 responden (24\%) menyatakan sering memperhatikan kriteria dalam menulis soal, dan ada yang menyatakan jarang dan tidak pernah; 3) Pelaksanaan ujian atau dalam melakukan kegiatan pengukuran, 49 responden (59\%) menyatakan selalu dan 13 responden (16\%) menyataan sering memperhatikan pelaksanaan ujian tersebut, sebagian lagi menyatakan kadang-kadang dan tidak pernah memperhatikannya; 4) Kegiatan penskoran yang dilakukan oleh dosen terhadap hasil ujian mahasiswa 29 responden (35\%) menyatakan selalu dan 10 responden (12\%) menyatakan sering memperhatikan ketentuan yang berlaku, dan sebagian lagi menyatakan kadang-kadang dan tidak pernah memperhatikannya; dan 5) Pelaksanan penilaian dan pengadministrasian hasil belajar mahasiswa, 23 responden (27\%) menyatakan selalu dan 30 responden (36\%) menyatakan sering memperhatikannya dan sebagian lagi responden menyatakan kadangkadang dan tidak pernah memperhatikannya.

Secara keseluruhan pelaksanaan penilaian hasil belajar mahasiswa oleh dosen UNP ratarata 54\% selalu dan sering dilakukan. Hasil penelitian ini lebih lanjut dikonversikan pada kriteria yang yang dikemukakan oleh Suharsimi Arikunto (1999: 123), maka dapat diartikan pelaksanaan penilaian hasil belajar mahasiswa berada pada kategori cukup baik dilaksanakan.

\section{Pembahasan}

Dari pengolahan data tentang pembuatan kisi-kisi tes yang dilakukan oleh dosen UNP, rata-rata hanya $42 \%$ menyatakan selalu dan sering memperhatikan pembuatan kisi-kisi tes. Dari temuan tersebut dapat disimpulkan bahwa pembuatan kisi-kisi tes berada pada kategori cukup baik dilakukan oleh dosen UNP.

Keadaan seperti ini tentulah perlu ditingkatkan lagi oleh para dosen UNP dalam melaksanakan tugasnya untuk melakukan penilaian hasil belajar mahasiswa. Pembuatan kisi-kisi tes berarti merencanakan secara jelas penilaian yang akan dilakukan dan merupakan salah satu kegiatan yang mesti dilaksanakan, agar penilaian dapat diberikan secara objektif. Karena temuan penelitian tentang pembuatan kisi-kisi tes diperoleh $42 \%$ ( kategori cukup). Hal ini mungkin disebabkan karena dosen malas membuat kisi-kisi tes, di samping itumungkin juga dosen kurang mempedomani prinsip-prinsip pembuatan kisi-kisi tes.

Dalam pelaksanaan evaluasi pembuatan kisikisi tes perlu dilakukan (Sudjana, 1999: 10), mengatakan bahwa kemampuan yang harus diukur serta proporsinya, lingkup materi yang diujikan serta proporsinya, tingkat kesulitan soal dan proporsinya, jenis dan alat dan penilaian yang digunakan, jumlah soal dan pertanyaan dan penilaian waktu untuk mengerjakan soal..

Berdasarkan pendapat di atas, pembuatan kisi-kisi tes mutlak dilakukan sebelum melaksanakan penilaian hasil belajar. Bila memperhatikan hasil penelitian masih banyak para dosen memilih kadang-kadang dan tidak pernah atau $58 \%$ dalam pembuatan kisi-kisi. Hal ini mungkin dosen beranggapan bahwa materi perkuliahan yang telah diberikan dapat diingat mana yang penting/ pokok yang akan diukur pencapaiannya oleh mahasiswa.

Setelah kisi-kisi tes dibuat maka tugas selanjutnya pembuatan/penulisan soal.Dari hasil pengolahan data tentang variabel penulisan soal hanya $37 \%$ dosen selalu dan sering memperhatikan kisi-kisi dalam pembuatan soal, serta sebanyak $63 \%$ responden yang menyatakan kadang-kadang dan tidak pernah memperhatikan kisi-kisi dalam penulisan soal.

Dengan demikian dapat dikatakan masih banyak dosen UNP dalam penulisan soal belum merancang secara sistimatis.ketepatan isi kurikulum, sehingga subyektifitas penilaian akan ada. Sesuai dengan pendapat (Sudjana 1989: 278) mengemukakan bahwa untuk mengurangi subyektifitas penilaian perlu dikembangkan format-format penilaian yang dapat dinilai oleh berbagai pihak yang bertugas sebagai penilai.

Dari temuan tersebut di atas, terlihat bahwa dalam membuat/menulis soal untuk evaluasi dosen UNP kurang memperhatikan atau mempedomani format-format kisi-kisi penulisan soal berdasarkan kriteria yang ditetapkan.

Selain bentuk soal bervariasi juga harus diperhatikan kriteria penulisan soal untuk masingmasing bentuk soal yang digunakan, sehingga soal 
yang dibuat benar-benar tepat untuk mengukur hasil belajar mahasiswa.

Dalam melaksanakan pengukuran diperoleh hasil pengolahan data sebagai berikut yaitu; ratarata $75 \%$ dosen UNP telah melaksanakan pengukuran sebagaimana mestinya. Dengan demikian dapat diartikan bahwa pelaksanaan ujian telah dilakukan dengan baik terutama dalam melakukan pengawasan pelaksanaan ujian secara umum.

Untuk mendapat mengetahui hasil pengukuran dosen harus melakukan pemeriksaan hasil pelaksaan ujian/pengukuran. Dari hasil pengolahan data ditemukan bahwa $92 \%$ dosen telah melakukan pemeriksaan terhadap jawaban ujian mahasiswa sebelum memberikan skor. Temuan ini juga menyiratkan bahwa terdapat dosen yang belum memeriksa lembaran jawaban mahasiswa atau sebanyak $8 \%$.terhadap soal, Dalam kegiatan penskoran ketiga cara yaitu: tanpa hukuman, dengan hukuman, dijawab dan tidak dijawab ada digunakan, tetapi yang cenderung dipakai yaitu menskor tanpa hukuman atau menghitung jawaban benar yang diperoleh mahasiswa, (40\%) menyatakan selalu dan sering. Namun ada sebanyak $(60 \%)$ juga yang menyatakan kadangkadang dan tidak pernah.

Berdasarkan hasil penelitian yang telah dilakukan dapat disimpulkan bahwa dosen UNP rata-rata sebanyak (53\%) kegiatan penilaian yang telah dilakukan oleh dosen-dosen UNP selalu dan sering melaksanakan kegiatan penilaian dan pengadministrasian hasil belajar mahasiswa sebagaimana mestinya dan ada yang menyatakan kadang-kadang dan tidak pernah melakukan sebagaimana mestinya sebanyak $47 \%$. Dengan demikian dapat disimpulkan bahwa dosen-dosen UNP telah menggunakan ketiga alternatif yang ada dalam menilai hasil belajar mahasiswa. Gabungan merupakan standar penilaian yang paling banyak dipakai.

Secara keseluruhan pelaksanaan penilaian dan pengadministrasian tes hasil belajar mahasiswa oleh dosen UNP berada pada kategori cukup baik dilaksanakan.

\section{Simpulan dan Saran Simpulan}

Pembuatan kisi-kisi tes yang dilakukan oleh dosen UNP dapat dikatakan dilaksanakan dengan cukup baik. Terlihat dari hasil penelitian rata-rata $42 \%$ selalu dan sering memperhatikan pembuatannya dan $58 \%$ menyatakan kadang-kadang dan tidak pernah memperhatikannya.

Dalam melakukan penulisan soal tes hasil belajar mahasiswa, sebanyak $37 \%$ dosen UNP menyatakan selalu dan sering memperhatikan kriteria penulisan, selain itu $63 \%$ menyatakan kadang-kadang dan tidak pernah memperhatikannya. Jadi penulisan soal yang dilakukan dapat dikatakan baik berada pada kategori kurang.

Kegiatan melakukan pengukuran/pelaksanaan ujian yang dilakukan oleh dosen UNP sudah dapat dikatakan baik, karena berdasarkan hasil penelitian $75 \%$ dosen UNP selalu dan sering memperhatikannya dan $25 \%$ menyatakan kadang-kadang dan tidak pernah.

Pelaksanaan kegiatan penskoran yang dilakukan oleh dosen UNP dapat dikategorikan masih cukup baik dilakukan karena, tak banyak responden atau $47 \%$ yang menyatakan selalu dan sering memperhatikan pelaksanaannya dan 53\% menyatakan jarang dan tidak pernah.

Kegiatan melakukan penilaian dan pengadministrasian tes hasil belajar mahasiswa, yang dilakukan oleh dosen UNP cukup baik dilaksanakan, karena baru 53\% responden juga menyatakan selalu dan sering, melaksanakannya dan selain $47 \%$ menyatakan kadang-kadang dan tidak pernah memperhatikannya dan melaksanakan.

\section{Saran}

Berdasarkan hasil penelitian yang telah didapat maka ada beberapa saran yang diajukan sebagai berikut:

Agar dosen UNP dapat meningkatkan pelaksanaan evaluasi hasil belajar sesuai dengan prosedur dan prinsip penilaian.

Ketua jurusan selingkungan UNP agar dapat melakukan pengawasan secara intensif terutama untuk mengetahui pelaksanaan evaluasi hasil belajar yang dilakukan oleh dosen yang ada di jurusan tersebut.

Pusat testing dan evaluasi UNP agar dapat membantu meningkatkan kemampuan dosen dalam melaksanakan evaluasi hasil belajar bagi mahasiswa seperti, melalui kegiatan penataran, seminar dan lokakarya. 
Peneliti lain yang berminat untuk melakukan penelitian serupa tentang pelaksanaan evaluasi hasil belajar mahasiswa yang dilakukan oleh dosen UNP, disarankan untuk dapat menggunakan sampel yang lebih besar, dan sub variabel yang lain, guna lebih melengkapi informasi tentang pelaksanaan evaluasi hasil belajar yang dilakukan oleh dosen UNP.

\section{Daftar Pustaka}

Arikunto, Suharsimi. 1999. Dasar-dasar Evaluasi Pendidikan. Jakarta: Bumi Aksara.

Buku Pedoman Akademik. 2001. Universitas Negeri Padang

Buchari, Muhctar. 1972. Technik-technik Evaluasi dalam Pendidikan. Bandung: Keluarga Mahasiswa Bapensi

Hadjar, Ibnu, 1996. Dasar-Dasar Metodologi Penelitian Kuantitatif Dalam Pendidikan. Jakarta: Raja Grafindo Persada

Nurkancana, Wayan. 1983. Evaluasi Pendidikan. Surabaya: Usaha Nasional.

Silverius. 1991. Evaluasi Hasil Belajar dan Umpan Balik. Jakarta: PT Grasindo.

Soekartawi. 1995. Monitoring dan Evaluasi Proyek Pendidikan. Jakarta: Pustaka Jaya.

Stufflebeam. 1972. D.L. Educational Evaluation and Decision Making, Peacock Publishers, Inc, Itasca. Sudjana, Nana. 1989. Penilaian Hasil Proses Belajar Mengajar. Bandung:PT Remaja Rosda Karya. 